\title{
THE HOME AS INSECURITY PLACE: VIOLENCE AGAINST WOMEN IN REAL LIFE
}

\author{
A CASA COMO LUGAR DE INSEGURANÇA: VIOLENNCIA CONTRA A MULHER NA \\ VIDA REAL
}

\section{Anancyara Késia MOREIRA ${ }^{\mathbf{1}}$; Luciana Aparecida Gadia FERNANDES ${ }^{2}$; Bruna Aparecida Rodrigues DUARTE ${ }^{3}$; Sarah Mendes de OLIVEIRA ${ }^{4}$; Guilherme Silva MENDONCA ${ }^{5}$; Marcelle Aparecida Barros JUNQUEIRA ${ }^{6}$; Carla Denari GIULIANI ${ }^{7}$}

1. Nurse at the Federal University of Uberlândia; 2. Nurse at the Federal University of Uberlândia; 3. Graduation of the Nursing Course by the Federal University of Uberlândia; 4. Nurse from the Federal University of Uberlândia, Master in Health Sciences from the Federal University of Uberlândia and professor at the University of Athenas in Paracatu; 5. Nurse, Master and Doctorate by the Graduate Program in Health Sciences of the Faculty of Medicine of the Federal University of Uberlândia. Works at the Dental Hospital Federal University of Uberlândia; 6. Lecturer at the Federal University of Uberlândia in the Undergraduate Nursing Course, doctor from the São Paulo University - Ribeirão Preto; 7. Lecturer at the Federal University of Uberlândia in the Nursing Undergraduate Program, doctor in History and Culture at the Uberlândia Federal University, Coordinator of the Advanced Laboratory in Gender and Violence (LGV) at the Federal University of Uberlândia.

\begin{abstract}
This study aimed to reach an understanding into how violence against women occurs, where it happens and who is the principle aggressor and their relationship with gender construction. We done a survey of written sources (patient medical records) from 2015, for those who were victims of domestic violence and were attended to at the Clinical Hospital - HCU. This information was cross-referenced in relation to nursing experience of undergraduates in nursing that developed home visits with a social assistant from a Basic Family Health Unit, in the city of Uberlândia-MG, over a timeline in 2016. After the analysis and taking into consideration the experience of women inserted within the scenario of violence, we noted that the victims of violence had already suffered some type of violence in the past and this repeats itself throughout their life and history, with the change of companion, and leaving the home due to family problems. There was a noted tendency toward the aggressor being someone known to or from the family, companion, boyfriend, friend, mother and father. The data also points to the aggressor as being predominantly from the masculine sex. Violence against women rubs shoulder to shoulder with categories of gender violence, class and their relationship of power. Such relationships are mediated by a prominent patriarchal order within Brazilian society, which gives to the man the right to dominate and control his wife, even to the point of violence.
\end{abstract}

KEYWORDS: Human behavior. Aggressiveness. Gender, domestic violence..

\section{INTRODUCTION}

In an attempt to bring domestic violence into a collective understanding, itself a diverse and multifaceted phenomenon, in and around 2015 a number of studies looked toward discussing domestic violence in the city of Uberlândia Minas Gerais Brazil. This city, in 1987 received the first Police Station Specialized in Attending Women of the Triangulo Mineiro, which specialized in providing a specific police service directed to women. Therefore, the victim of violence can register the occurrence, receive a detailed statement and request a physical examination. This in itself helps to produce an environment with less intimidation for women than the general police station, thus facilitating the reporting of violence (SILVA; BORGES, 2013), as the combating of such can only be achieved, when it passes from the four walls of the private environment and becomes public. After this advance, the city received the
NGO called SOS Family Woman Action of Uberlândia, with the aim of attending to other existing needs of the victims of violence, covering in this way the whole family environment, for women, children and even men victim of domestic violence, directed toward promoting martial and family peace. "The NGO SOS Family Woman of Uberlândia is today a Non-Governmental Organisation, a Municipal and Federal Public Utility and counts on free inter-professional work, which acts upon and intervenes in cases of domestic and interfamily violence, be that physical, sexual, patrimonial and/or psychological/emotional/moral. Here the strategies of assistance can be individual, as a couple or in reflective support groups with women, men the protagonist of the violence, children and adolescents." (GUERRA; LEMES, 2003). The fact that social assistance is seen as a means of helping women break the cycle of violence and get back their social dignity, results in a differentiation in the NGO (SILVA; BORGES, 
2013). The city also advanced with the creation of the Women's Patrol Service in 2003, in partnership with SOS Woman and Family, 17th Battalion, the local council and the Federal University of Uberlandia, which offers home assistance to victims of inter-familiar violence, through an interdisciplinary and interinstitutional team, which can be put into action by 190 or police statements, filed with the military police (SILVA; BORGES, 2013).

According to the Map of Violence of 2012 (WAISELFISZ, 2012), Brazil is the 7th highest country in terms of homicides, with a rate of $27.4 \%$, and in 8th position, $54.5 \%$ or homicides among the young population. While in 2012, the same map shows that $91.6 \%$ of homicides occur in the masculine population, which can lead to a lowering in importance of the deaths within the feminine sex. However, emphasis in this study is given to gender violence that causes the highest number of deaths in women, and more specifically in the domestic environment.

In this context, one looks for an understanding on a micro level by means of crossreferencing written sources and experiences from students into the historical roots of violence, such as the continuation of women in violent marital relationships, and use of real life stories. Through observing their experiences of violence in a study, the women point out that in general, these acts of violence occur on a domestic level and that many times by people known to them that should take the role of protector and not perpetrator of violence (MAIA, 2012). The thing that caught our attention was the need to show the problem between gender violence and the home environment.

In order to contemplate domestic violence and its implications for women, it is necessary to reexamine some of the questions that have come forward in discussions over the last decades of the $20^{\text {th }}$ century and the beginning of the $21^{\text {st }}$ century. The theme of violence against women became the focus of debate at the end of the 1970's; this was a result of a broad mobilization and public voicing on the part of the feminist movement. Slowly, this gained pace until becoming a political category built by feminists to voice their opinion against inequality and domestic violence. "The people are politics", a slogan from manifestations of the period, this amply expressed the character of the first demands: the public awareness of the oppression of women, the criminalization of the violence suffered, the condemnation of the assassination of women "for love" and "in the defence of honour", and mainly the transformation of "domestic violence" practiced in the private environment into a public, political and State concern (BRANDÃO, 1998). Therefore domestic violence, which according to Cortês "is a social problem that affects thousands of women on a daily basis worldwide, being a manifestation that is conceptualized as gender violence, and affects women of all ages, of various social classes, regions, ethic-racial groups, levels of education, sexual orientation and religion" (CÔRTES, 2012), which can have a relationship with patriarchal society that formats a scenario where the punishment is natural, in situations where there is a feeling of shame, "in doing something that was considered shameful, the woman stained the reputation of the men to whom she belongs - sons, husband, brothers, therefore the stain should be removed by means of aggression." (COLLING; TEDESCHI, 2012).

After perceiving the severity of violence against women, it is necessary to understand that "it is a serious public health problem, due to its magnitude, severity, recurrence and negative consequences on the quality of life of the victims" (AMARIJO, 2017), health services have been happening daily, mainly in primary care8, so professionals need to be able to deal with this situation, observe characteristics that may suggest insertion into the violence scenario, as well as evaluate these victims in a holistic way, not focusing only on the physical symptoms. We know that there are factors that can influence the reception and treatment, some of them, the social representation configured as "set of thoughts, ideas and beliefs resulting from social interactions, common to a given group of individuals" (AMARIJO, 2017), which influences the reception and follow-up treatment, as well as the fear of involvement and reprisals or insecurity in dealing with the situation, "doctors fear for their personal safety, they do not want to get involved in judicial matters, they do not know where to refer women, and they do not believe that the health service is an adequate place to treat cases of violence" (FERRANTE; SANTOS; VIEIRA, 2009). Another factor that may influence this treatment is the biomedical model, focused on biological issues, often disqualifying the suffering of women seeking health services. In another aspect, when there is a sensitivity on the part of the health professional to meet the demands placed by the victimized woman, there are reports of a lack of theoretical background on the problem of violence, and lack of technical and institutional resources to provide quality support (COSTA, 2011). 
A positive fact is that after the broad discussion about gender violence in recent years, as shown above, it was possible to achieve a situation that was previously unthinkable, and it made the society aware of the need to denounce, protect, support and activate mechanisms to repress violence to which women are subjected every day. "Although the traditional forms of relationship between the sexes are frequent, there has already been room for disagreement, since what was the private realm of each became public and became a political issue" (CARDOSO, 1985).

However, with more than three decades having gone by since the feminist movements, and even with the institutional and political conquests; physical and psychological violence, coercion and torture, emotional blackmail, misogynist intimidation still make up a perverse reality for many women. The social advances, both cultural and legislative, have not inhibited violent practices, which still continue to happen (BOSCH; FERRER, 2002). In legislative terms, law $N^{\circ} 11.340 / 2006$, known as the law Maria da Penha, although the target of criticism, has been considered as a major advance in the effort to eradicate violence against women, as through it the Courts of Domestic and Family Violence against women were established, which increased the sentence of the crime of Domestic Violence and vetoed the use of law $n^{\circ}$ 9.099/95, better known as the Special Crimes Court, for dealing with such crimes. In addition, the law widened and brought in other crimes against women in the domestic environment, and did not remain restricted to only heterosexual relationships in the definition of domestic or family violence as a whole, but included any action or omission based on the genre that leads to death, lesion, any physical, sexual or psychological suffering as well as moral and/or patrimonial impairment within the sphere of the domestic unit, of the family or in any intimate relationship of affection, in which the aggressor lives or has lived with the abused/victim (CELMER, 2007).

The various perspectives appear in the form of analyses based on the different professional experiences, in the theoretical and methodological references of each area of knowledge, which are themselves permeated by the interest in the study of the women, of the violence against them and traversed by the category of analysis, built through the conceptions of the feminist gender. Gender is constituted therefore in the cement that will bind the various questions faced by the researchers. Therefore, this study aimed to reach an understanding into how violence against women occurs, where it happens and who is the principle aggressor and their relationship with gender construction.

\section{MATERIAL AND METHODS}

The study was developed in the municipality of Uberlândia, State of Minas Gerais, Triângulo Mineiro region. The methodological layout was based on a retrospective qualitative study with an analysis of reports (alert cards and compulsory violence notifications) of women victims of violence attended at Clinical Hospital of the Federal University of Uberlândia (CH-UFU), in 2015 , together with a descriptive study of the type of experience reported, with two interviews from women victims of domestic violence, who were attended at Family Health strategy centres in the suburbs of Uberlândia, in 2016.

The research subjects were women victims of gender violence that sought health assistance from CH-UFU, at the Family Health Strategy centre in the suburbs of the same city. This group was constituted of 18 victims of domestic gender violence attended at the $\mathrm{CH}-\mathrm{UFU}$, where health professionals reported they had suffered from violence, through the Alert record and from reports with complete data, in 2015. These were nominated by a number system, in order to maintain anonymity.

For greater understanding into the processes of violence, we brought together data obtained from reports and from Alert cards, in 2015, two interviews that had a semi-structured guide, in order to obtain the life stories that correspond to questions: 1- family life: construct being a girl; 2Life at school: construct being a girl and a boy; $3-$ Adolescent: construct on the sexuality of the young girl; 4- interpersonal and affectionate relationships: ways of being a man and a woman, the exercising of sexuality and power; 5- lived situations of violence: health, social life, interpersonal relationships (partner). The interviews were performed through home visits by nursing students, with patients that had already been attended at Family Health strategy centres in the suburbs of Uberlândia Minas Gerais, in 2016, all victims of violence.

The study was approved by local Ethics Committee (CAAE: 1496121330005146).

\section{RESULTS AND DISCUSSION}

It was observed 18 aggressions documented on alert cards in 2015, and only three were unknown, that is, $17 \%$ of the unknown men were 
not part of the family, 15 aggressors or $83 \%$ of the sample were part of the family. The data also revealed that $100 \%$ of the perpetrators are male, $100 \%$ of the victims of violence are women between the ages of 13 and 72 years, where $100 \%$ of these violent acts occur within the residence of these women. It was also revealed that $83 \%$ of physical and sexual violence and $17 \%$ sexual violence were accompanied by rape with unknown perpetrators (Table 1).

Table 1. Data from the alert card of women victims of domestic violence attended at HC-UFU in the year 2015.

\begin{tabular}{|c|c|c|c|c|c|c|}
\hline $\begin{array}{l}\text { Number of } \\
\text { victims }\end{array}$ & Aggressor & $\begin{array}{l}\text { Sex } \\
\text { Abuser }\end{array}$ & $\begin{array}{l}\text { Victims } \\
\text { of } \\
\text { violence }\end{array}$ & $\begin{array}{l}\text { Age of } \\
\text { victims }\end{array}$ & $\begin{array}{l}\text { Location of } \\
\text { aggression }\end{array}$ & $\begin{array}{l}\text { Type of } \\
\text { aggression }\end{array}$ \\
\hline 1 & Stepfathers & Male & Female & 13 years & Residence & Sexual \\
\hline 2 & Husband & Male & Female & 25 years & Residence & Physical \\
\hline 3 & Husband & Male & Female & 23 years & Residence & Physical \\
\hline 4 & Son in law & Male & Female & 45 years & Residence & Physical \\
\hline 5 & Known friend & Male & Female & 49 years & Residence & $\begin{array}{l}\text { Sexual and } \\
\text { Physical }\end{array}$ \\
\hline 6 & Spouse & Male & Female & 35 years & Residence & $\begin{array}{l}\text { Sexual and } \\
\text { Physical }\end{array}$ \\
\hline 7 & Spouse & Male & Female & 32 years & Residence & $\begin{array}{l}\text { Physical } \\
\text { sexual }\end{array}$ \\
\hline 8 & Unknown & Male & Female & 20 years & Residence & Sexual rape \\
\hline 9 & Paternal uncle & Male & Female & 55 years & Residence & Sexual \\
\hline 10 & Known friend & Male & Female & 64 years & Residence & $\begin{array}{l}\text { Physical and } \\
\text { sexual }\end{array}$ \\
\hline 11 & Spouse & Male & Female & 30 years & Residence & $\begin{array}{l}\text { Physical and } \\
\text { sexual }\end{array}$ \\
\hline 12 & Unknown & Male & Female & 51 years & Residence & Sexual rape \\
\hline 13 & Unknown & Male & Female & 26 years & Residence & Sexual rape \\
\hline 14 & Stepfather & Male & Female & 18 years & Residence & Sexual rape \\
\hline 15 & Known friend & Male & Female & 72 years & Residence & $\begin{array}{l}\text { Physical and } \\
\text { sexual }\end{array}$ \\
\hline 16 & Neighbor & Male & Female & 19 years & Residence & Sexual rape \\
\hline 17 & Spouse & Male & Female & 35 years & Residence & $\begin{array}{l}\text { Physical and } \\
\text { sexual }\end{array}$ \\
\hline 18 & Spouse & Male & Female & 34 years & Residence & $\begin{array}{l}\text { Physical and } \\
\text { sexual }\end{array}$ \\
\hline
\end{tabular}

Sources written removed from the alert of 2015, of women victims of violence attending HC-UFU.

Although the concept of domestic violence considers that the phenomenon can occur inside or outside the home, the place of residence is still the place in which it predominantly occurs.

On the Alert Medical Report of victim 9 the authors found:

\section{Victim: 18 years of age}

Aggressor: step-father.

Location: Residence. Victim of sexual aggression, 4 months pregnant. The patient came to the health clinic with her mother and sister, they reported that she had suffered sexual abuse over a period of 4 months, which resulted in her current state of pregnancy. The patient suffered from poliomyelitis, according to the report her abuser was the mother's companion with whom she was living, the three lived in his house and twice the mother saw her partner have sexual relations with her daughter, the abuser said he would deny it if she told anyone. Abortion performed.

The feminine body so widely exalted as an expression of beauty is also a place of violence, whether it be physical violence - beatings, rape among others - that are well known, or those other subtle and ingenious forms of violence, which on many occasions are perpetrated against children and adolescents, all of which mark the life of women 
across all their stages (MATOS; SOIHET, 2003). A research study performed in São Paulo, pointed to the predominance of sexual aggression, sexual abuse or rape against children and adolescents of the feminine sex in the domestic environment, perpetrated especially by fathers or step-fathers (RIBEIRO; FERRIANI; REIS, 2004).

If we take into consideration the violence of gender, implicit in the acts of rape and sexual abuse against girls, who justifies the act of the sexual aggressor base themselves on the ideology of the difference in the exercising of masculine and feminine sexuality. Hence, there exists the continuation of the idea of the uncontrollable masculine desire and that feminine sexuality only emerges when incited (SAFFIOTI, 2004).

In the specific case of sexual violence against girls and adolescents, it is important to take into account power asymmetries implicit in such acts. Violence from adults toward children and adolescents is characterized through the imbalance of power between the parts. Such imbalances are deepened when the power asymmetries between generations are added through questions related to the feminine body object that can be touched, violated without any type of consent (SANDERS, 2005).

The majority of arguments from rapists and defence lawyers of the accused is that "through the committing of such a crime, the man to a certain degree is a victim of his own virile nature, in acting upon the sexual appeal inherent to their being, and as such, appropriates the body of the woman", in this manner the role of perpetrator and victim are inversed, where the woman is "guilty" for turning on the incontrollable sexual desires within the man. In a study that presents reports from rape victims, among other reports, one from a woman that was raped for the first time at the age of nine years of age, asked the question of why is the woman always to blame for being the victim of sexual violence, if at the time of the occurrence, she was so thin that she still did not have the curves of a woman's body when she was raped (NUCCI, 2012).

Even after the sexual revolution of the 1960 's, the changes in the affective-sexual relationships between men and women have not undergone any radical change as was hoped, and there are still many steadfast stereotypes of femininity and masculinity that define the exercising of masculine and feminine sexuality. The silence behind relationships that go on within the private environment of the home is still a factor that brings difficulties in the making changes and providing protection to women that suffer abuse. The study noted the predominance of female victims with a history of sexual and physical aggression, over the 18 to 72-year-old age group, sexual and physical violence was prevalent in $69.0 \%$, followed by sexual abuse at $12.5 \%$, and physical violence at $6.25 \%$. In what refers to the location where the aggression occurs, in those reports examined there was a $100 \%$ reporting of aggressions occurring in the home. Although the concept of domestic violence considers that the phenomenon can occur inside or outside of the home, the residence is still the place where it happens as a rule $(\mathrm{BOZON}$, 2004). Around $48 \%$ of women state that they have been victims of violence within their own home. In the case of men, only $14 \%$ were beaten in the home. As one notes here from our study, unfortunately, the larger number of aggressors are men that have or have had a relationship with the victim. The Brazilian data are alarming: three out of five youths have been beaten by their companions (BOTTO, 2015). As shown in the statements of MS in ESF Canaã neighbourhood Uberlândia 2016:

"It was his birthday we went out as normal, I gave him a present and then in the car he said: we are going over there now. There where? I asked and he said: there! He took me to a motel, a place that I had never been to in my life, I was 19 years old, I had never known a man in this way, I had had boyfriends, but none had gone this far, but there he took me. I said that I would not go in. He said to me: no, yes you are. I had only been dating him for 7 months but I trusted him. I was sure that he would not do anything that I didn't want to! But it did not happen that way. We entered and I stayed in the corner and he came over, I said that I didn't want to, but he was already taking off my clothes by force, I was trying to get out, he was much stronger than me. I was ashamed and embarrassed, I was afraid, I was paralysed. I remember that when he started to force me was when I started to shout, he put his hand over my mouth and with the other he held both of my hands, he held my body and did whatever he wanted, without any care for my feelings, he raped me."

Violence afflicts women and men in different and distinct forms. A majority of the violence committed is against women and practiced in the private environment, while that which afflicts men occurs in greater part on the streets. One of the main types of violence used against women occurs in the home, where it is carried out by individuals of their living circles, such as husbands/wives or companions, and where it is carried out in many forms, from physical to psychological and verbal abuse. The place where there should exist a 
relationship of affection and respect, there exists a relationship of violence, which on many occasions is invisible as it is attached to roles that are culturally attributed to men and women. Such a situation makes it difficult to denounce and report, as it puts the abused woman in a situation even more prone to violence (BOZON, 2004; BOTTO, 2015).

According to data from 2006 to 2010 from the World Health Organization, Brazil is among the top ten countries of the world for the number of feminine homicides. This datum is still further alarming when one understands that in $90 \%$ of cases, the homicide against women is committed by men with whom the victim had an affective and stable relationship, at the woman's very residence (BRASIL, 2004). In addition, the interviews and data collected demonstrate that sexual and physical violence were prevalent at $69.0 \%$, as shown in some of the Alert reports obtained at the hospital de clinicas da Universidade Federal de Uberlândia in 2015:

Victim 1: 49 years old. Aggressor: Friend/acquaintance

Location: Home. Victim of sexual and physical violence. The patient reported that during the early hours of this particular morning, she was the victim of a break in by someone known and who lived in the neighbourhood. He broke into the house saying that she would have to stay with him, as she refused he physically attacked her with bunches and a broomstick, the victim reported that there was vaginal penetration, but denies there being oral or anal sex.

\section{Victim 2: 35 years old. Aggressor: Spouse.}

Location: Home. The patient was brought to Health Centre by the police, a victim of sexual and physical aggression. She reports that during the night her spouse (a stable union of 6 months) assaulted her both psychologically and sexually (anal and oral). The fact occurred under a bridge and after at home. The aggressor was under the influence of drugs (cocaine and alcohol).

Victim 3: 32 years old. Aggressor: Husband.

Location: Home. The patient reported that one day ago, after an argument with her husband and subsequent physical and sexual aggression, she started to feel a strong pain in the lower region of her belly, which was accompanied by vaginal bleeding, bright red in large volume and now she bleeds permanently.

One of the most important instruments for addressing domestic and family violence against women is the law Maria da Penha - Law No. 11.340/2006. This law, besides defining and typifying the forms of violence against women (physical, psychological, sexual, patrimonial and moral), it also provides the means for the creation of specialized services, such as those which include the Network for Addressing Violence against Women, composed of public institutions of security, justice, health and social assistance. The law Maria da Penha also obtained an important victory in February of 2012, with a decision in the Supreme Court (STF), when it established that any person can formally register a statement of violence against a woman, and not only who has suffered the violence (CELMER, 2007). Violence from the male to the woman is expressed in different forms, irony, beatings, forced reproduction, rape, homicide etc., and is constitutive in the social gender organization of Brazil. As a rule, sexual violation is only considered an act of violence when practiced by those outside of the matrimonial contract, and as such seen as acceptable when it occurs within the confines of marriage. In other words, once married, de jure or de facto, the woman is constituted as part of the property of the man, and to whom she needs to be sexually ready at his whim (SAFFIOTI, 1994).

In this manner, one understands gender violence through feminine contributions to the study of gender violence. Gender violence is a broad concept, covering victims such as women, children and adolescents of both sexes. In the exercising of the patriarchal function, men hold the power to determine the conduct of socially nominated categories, receiving authorization, or at least, tolerance from society to punish that which is presented to them as a challenge (SAFFIOTI, 2002). Although there has not been any push, on the part of potential victims, to force different paths to those prescribed by social norms, the execution of the project of dominance-exploration of the social category of men, demands that their capacity to rule is aided through violence.

Studies based on violence against women in Brazil have made important empirical and theoretical contributions toward the visibility and understanding of this phenomenon. The plotting of criminal statements, the debates into the position of the "victim" and the investigations into the calls made to health institutions, have revealed that violence against women is a serious problem in Brazilian society. The notion of patriarchal domination is insufficient per se to account for the changes that have been taking place in the different roles that women in situations of violence have assumed, and an approach to violence against 
women as a relationship of power needs a deeper understanding. This power is no longer understood as absolute and static, exercised as a rule by the man on the woman, as we would like to believe is the approach of patriarchal domination, but in a dynamic and relational form, exercised by both men and women, albeit unequally. It becomes necessary to define "gender violence" through greater theoretical rigor, thus incorporating all the aspects of the concept of gender as put forward by Joan Scott, using above all her reference to gender as a playing field where power is articulated and broadens the perspectives of gender, without excluding the different social categories from the analyses concerning violence against women in Brazil, with a greater understanding, not only of the role of women in relationships of violence, but also the role exercised by men.

The health area needs to revitalize its theoretical perspective of domination-victimization. This revitalization becomes evermore necessary in order to gain an understanding into how, not only women, but also how men participate and provide significance to violence against women, especially in social-cultural contexts. Therefore, one points to the difficulty of taking the debate concerning revitalization of feminist practices in and out of the Health-State. On one hand, it contributed to providing greater visibility toward the phenomenon of violence against women, on the other, it placed the woman in a "straitjacket", relegating them to a position of passivity in relation to the control of men. In Brazil, the intervention and research studies focused specifically on men in the field of violence against women are relatively recent.

In light of this difficulty, it is understood that there is the necessity to continue onward in the debate concerning the place of the women in a situation of violence, as well as develop more research regarding the professional qualification of health assistants that attend to women in situations of violence, all aimed at theoretical and practical alternatives for improving the situation of women that face violence as part of their reality.

RESUMO: Este estudo objetivou compreender como ocorre a violência contra a mulher, onde e quem é o principal agressor, e sua relação com as construções de gênero. Foi realizado um levantamento de fontes escritas (prontuários de pacientes) do ano 2015, referente às vitimas de violência domestica e atendidas Hospital das Clínicas HCU. Esses dados foram cruzados com relatos de experiência de graduandos em enfermagem que desenvolveram visitas domiciliares com assistente social de uma Unidade Básica de Saúde da Família, na cidade de Uberlândia-MG, em um espaço temporal do ano 2016. Após analise e levando-se em consideração a vivência com as mulheres inseridas no cenário de violência, foi possível notar que as vítimas de violência já sofreram algum tipo de violência no passado e que essas se repetem ao longo da vida e sua história, com a mudança de companheiro, com saída de casa devido à problemas familiares. Observou-se que o agressor é alguém conhecido ou mesmo da família, companheiro, namorado, amigo, mãe e pai. Os dados demonstraram uma predominância de sexo do agressor masculina. A violência contra a mulher traz em seu seio, estreita relação com as categorias de gênero, classe e suas relações de poder. Tais relações estão mediadas por uma ordem patriarcal proeminente na sociedade brasileira, a qual atribui aos homens o direito a dominar e controlar suas mulheres, levando aos limites da violência.

PALAVRAS-CHAVES: Comportamento humano, Agressividade. Gênero. Violência doméstica.

\section{REFERENCES}

AMARIJO, C. L.; GOMES, V. L. O.; GOMES, A. M. TOSOLI; FONSECA, A. D.; SILVA, C. D.. Representação social de profissionais de enfermagem acerca da violência doméstica contra a mulher: abordagem estrutural. Rev enferm UERJ, Rio de Janeiro, v. 25, p. e23648, 2017. DOI: http://dx.doi.org/10.12957/reuerj.2017.23648

BRASIL. Ministério da Saúde. Secretaria de Atenção à Saúde. Departamento de Ações Programáticas Estratégicas. Política Nacional de Atenção Integral à Saúde da Mulher: princípios e diretrizes. 2004. 80 p. [acesso em 26 jan 2017]. Disponível em: http://bvsms.saude.gov.br/bvs/publicacoes/ politica_nac_atencao_mulher.pdf.

BRASIL. Presidência da República. Lei Maria da Penha. Lei n. 11.340/2006. Coíbe a violência doméstica e familiar contra a mulher. 2006. 
BOSCH, E.; FERRER, V. A. La voz de las invisibles. Las víctimas de un mal amor que mata. Valéncia: Cátedra, 2002, 304 p., ISBN: 9788437620152.

BOTTO, C. A casa é o lugar mais inseguro para a mulher. Feminino e Além [periódico na internet] Jul 2015. [acesso em 20 jan 2017]: [cerca de 1p]. Disponível em: http://femininoealem.com.br/14151/a-casa-e-o-lugarmais-inseguro-para-a-mulher/

BOZON, M. Sociologia da sexualidade. Rio de Janeiro: FGV, 1 ed., 2004, 172 p., ISBN: 85-225-0486-5.

BRANDÃO, E. R.. Violência conjugal e o recurso feminino à polícia. In: BRUSCHINI, C.; HOLANDA, H. B. Horizontes plurais: novos estudos de gênero no Brasil. São Paulo: Fundação Carlo Chagas, 34 ed.,1998. ISBN: 85-7326-084-X.

CARDOSO, R. Prefácio. In: CHAUÍ, M.; CARDOSO, R.; PAOLI, M. C. (Org.). Perspectiva antropológica da mulher 4: sobre mulher e violência. Rio de Janeiro: Editora Zahar, 1985.

CELMER, E. G.. Violência conjugal contra a mulher: refletindo sobre gênero, consenso e conflito na justiça criminal. Ártemis, João Pessoa, PB., v. 6, p. 26-37, 2007. ISSN 1807-8214.

COLliNG, A. M.; TEDESCHI, L. A. Dicionário Crítico de Gênero. Dourado, MS: Ed. UFRGD, 2015.

CÔRTES, G. R. Violência doméstica: centro de referência da mulher "Heleieth Saffioti”. Estudo Sociologia. Araraquara: Estudo de Sociologia, v. 17, n. 32, p.149-168, 2012.

COSTA, L. H. R.. Estendendo o Fio de Ariadne: sexualidade feminina e a interseção com o cuidado nos discursos de enfermeiras [tese doutorado]. Universidade Federal da Bahia, Programa de Pós-Graduação em Enfermagem. Salvador, 2011.

FERRANTE, F. G.; SANTOS, M. A.; VIEIRA, E. M. Violência contra a mulher: percepção dos médicos das unidades básicas de saúde da cidade de Ribeirão Preto, São Paulo. Red de Revistas Científicas de América Latina y el Caribe, Espanã y Portugal, 2009.

GUERRA, C. C.; LEMES, V. Casa abril Travessia de Uberlândia para mulheres e filhos/as em risco: uma alternativa à violência intrafamiliar. Uberlândia: Gênero em Pesquisa - PPGH, n.19/20, 2002-2003

MAIA, C. J. Rompendo o silêncio: histórias de violência conjugal contra mulheres no norte de Minas (19702007). In: MAIA, C. J.; CALEIRO, R. C. L. (Org).. Mulheres, violência e justiça no Norte de Minas. São Paulo: Annablume, 2012, p. 15-52. ISBN 978-85-391-0353-9.

MATOS, M. I. S.; SOIHET, R.. O corpo feminino em debate. São Paulo: UNESP, 1 ed., 2003. 224 p., ISBN: 857139458X.

NUCCI, G. S. Código penal comentado. São Paulo: Revista dos Tribunais, 11. ed., rev., atual. e ampl., 2012, 1373 p.,. ISBN: 9788520342602.

RIBEIRO, M. A.; FERRIANI, M. G. C.; REIS, J. N. Violência sexual contra crianças e adolescentes: características relativas à vitimização nas relações familiares. Cad. Saúde Públ., Rio de Janeiro, v. 20, n. 2, p. 456-64, 2004. ISSN 1678-4464. http://dx.doi.org/10.1590/S0102-311X2004000200013.

SANDERS, S. W. Ativo para a vida: programas de movimento adequados ao desenvolvimento da criança. Porto Alegre: Artmed, 2005. 128 p., ISBN: 9788536302188.

SAFFIOTI, H. I. B. Gênero, patriarcado e violência. São Paulo: Fundação Perseu Abramo, 1 ed., 2004. 150 p., ISBN/ISSN: 2147483647. 
SAFFIOTI, H. I. B. Violência de gênero no Brasil atual. Revista Estudos Feministas, Santa Catarina, (n.e), p. 443-61, 1994. ISSN 1807-1384.

SAFFIOTI, H. I. B. Contribuições feministas para o estudo da violência de gênero. Labrys: estudos feministas, Brasília, n. 1, p. 1-2, 2002. ISSN: 1676-9651.

SILVA, L. J.; BORGES, D. T. B. Violência conjugal e intrafamiliar: Breve história da ONG SOS Ação Mulher Família e instituições públicas que combatem a violência contra a mulher em Uberlândia - 1985/2011.

Caderno Espaço Feminino, Uberlândia, v. 26, n. 1 - Jan/Jun.2013

WAISELFISZ, J. J. Mapa da Violência 2012. Os novos padrões da violência homicida no Brasil. São Paulo, Instituto Sangari, 2012. 